\title{
Biochar and swine wastewater: Effects on soil fertility of different textures and corn nutrition
}

\author{
Erivelton Gonçalves da Cunha ${ }^{1}$, Rebyson Bissaco Guidinelle ${ }^{2 * \mathbb{D}}$, \\ Otacilio José Passos Rangel ${ }^{3}$, Renato Ribeiro Passos ${ }^{2}$ \\ 10.1590/0034-737X202168060011
}

\begin{abstract}
The use of organic waste in agriculture has stimulated the search for technologies that reduce environmental pollution. Among the residues are the biochar and swine wastewater (SW), which incorrectly disposed cause negative impacts, however, when combined, they can enhance agricultural production, due to the synergism between both.

In this sense, the objective was to evaluate the influence of doses of biochar, from conilon coffee straw, combined or not with swine wastewater diluted to 50\% (SW50\%), on the nutrient content in medium and clayey texture soils and in the corn plant tissue. The experiment was carried out in a greenhouse, with five doses of biochar, two irrigation waters and two soils, with three repetitions. The $\mathrm{pH}, \mathrm{P}, \mathrm{K}^{+}, \mathrm{Ca}^{+2}, \mathrm{Mg}^{+2}, \mathrm{Zn}^{+2}$ and $\mathrm{Na}^{+}$in the soil and $\mathrm{N}, \mathrm{P}, \mathrm{K}, \mathrm{Ca}, \mathrm{Mg}, \mathrm{Zn}$ and Na in plant were evaluated. The addition of biochar in doses linearly increased the levels of $\mathrm{P}$ and $\mathrm{K}^{+}$in both soil textures, with synergy when irrigated with SW50\%. The SW50\% provided a nutrients increase in the corn plant tissue. The agricultural use of biochar from conilon coffee straw was important to increase the content of $\mathrm{P}$ and, mainly, $\mathrm{K}$ in the aerial part of corn.
\end{abstract}

Keywords: biochar, coffee straw, corn nutrition, nutrient availability, swine slurry, water reuse.

\section{INTRODUCTION}

The use of residues from agricultural activities in agriculture has been constantly studied by researchers in search of improvements in environmental conservation and productivity, mainly related to the cycling of nutrients and the increase of soil organic matter (Pires \& Mattiazzo, 2008).

Biochar is the product obtained from the thermal decomposition of organic waste, in an environment with low oxygen availability and temperatures that can vary from 250 to $700^{\circ} \mathrm{C}$, by the pyrolysis process (Lehmann \& Joseph, 2015). Biochars, when compared to in natura biomass, have the advantage of providing nutrients and carbon to the soil, which can change chemical attributes, due to the transformation of open chain carbon into carbon of stable aromatic structure, through dynamic and reversible interactions with nutrients and mineral particles in the soil. That way, aiding in the retention, availability and increase of nutrients, promoting better nutritional performance of plants grown in nurseries or in the field (Enders et al., 2012; Novotny, 2014).

Depending on the material that originated the biochar, it can provide more or less nutrients (Akhtar et al., 2015). According to Barbosa (2016), the biochar from coffee straw has a high concentration of potassium and phosphorus, enhancing its use in agriculture. Corroborating this statement is the conclusion of the work by Alvarenga (2019), where the increase in the $\mathrm{K}$ content available in the soil was directly proportional to the doses of coffee straw biochars applied, reinforcing the evidence there is the work developed by Fonseca et al. (2020), where the authors concluded that coffee straw biochars are efficient in promoting the optimization of phosphate fertilization, providing the largest accumulation of phosphorus in the aerial part of plants.

\footnotetext{
Submitted on July $8^{\text {th }}, 2020$ and accepted on April $7^{\text {th }}, 2021$.

' Instituto Capixaba de Pesquisa, Assistência Técnica e Extensão Rural, Espírito Santo, Brazil. eriveltoncunha.ufv@gmail.com

${ }^{2}$ Universidade Federal do Espírito Santo, Campus de Alegre, Alegre, Espírito Santo, Brazil. rebysonguidinelle@gmail.com; renatoribeiropassos@hotmail.com

${ }_{3}^{3}$ Instituto Federal do Espírito Santo, Campus de Alegre, Alegre, Espírito Santo, Brazil. otaciliorangel@gmail.com

*Corresponding author: rebysonguidinelle@gmail.com
} 
The State of Espirito Santo, Brazil, stands out as the largest Brazilian producer of Conilon coffee (CONAB, 2020), being coffee straw the main waste generated during the processing, and that incorrectly disposed of contributes to the proliferation of pests, like the stable fly (Stomoxys calcitrans). For this reason, Ordinance N. 23-R of 2003, prohibits the use of coffee straw in the decomposition phase as a source of organic material, without adequate prevention measures, which is one of the limiting aspects of its agricultural use (Espírito Santo, 2003). Therefore, it is of great importance to study new technologies that enable the use of this residue in agriculture.

Another organic waste suitable for agricultural use is the swine wastewater (SW), the State of Espírito Santo is not the largest Brazilian producer, but according to Effgen (2014), a volume of $2,000 \mathrm{~m}^{3}$ of swine wastewater is launched in the State on a daily basis, a material rich in nutrients, which has aroused the interest of researchers.

Many authors have reported the use of SW, in substitution or complementation of mineral fertilization, as a way to supply the water and nutritional needs of agricultural crops (Freitas et al., 2004; Moreira et al., 2015).

However, the agricultural use of SW in large quantities or inappropriately can negatively affect the plant nutrition and development due to problems such as nutrient imbalance in the soil (Seganfredo, 2000; Dal Bosco et al., 2008). There is also an environmental risk, since the use of SW in agriculture can increase the concentration of potentially saline ions and heavy metals in the soil, due to the high concentration mainly of sodium, zinc and copper in the SW (Pereira, 2006).

As a way to mitigate the negative effects of the use of waste or saline water in irrigation, some authors have studied its interaction with biochar. The results obtained are encouraging because, in addition to attenuating the harmful effects of the salinity and toxicity of some ions, biochar improves soil attributes, the absorption of nutrients by plants increases plant production (Akhtar et al., 2015; Costa, 2017), and further enhances the agricultural use of wastewater from various activities.

In view of this, it is expected that the agricultural use of biochar from conilon coffee straw and SW promotes an increase in the levels of nutrients in the soil and in corn plants, culture that was chosen for evaluation, due to its fast cultivation cycle and socioeconomic importance of world order, being used in human and animal feeding, its insertion in this study is relevant in order to enrich the literature.

Therefore, this study aimed to evaluate the influence of doses of biochar from conilon coffee straw, combined or not with SW diluted to $50 \%$, in the nutrient content in soils of different textures and in the nutrition of the corns plants.

\section{MATERIALAND METHODS}

The study was conducted in a greenhouse at the Federal Institute of Espírito Santo (Ifes), Campus de Alegre, located in the municipality of Alegre, state of Espirito Santo, Brazil. The region's climate is tropical, with an average annual temperature of around $23^{\circ} \mathrm{C}$. The experimental design used was in randomized blocks, with three replications. The experiment was implemented in a $5 \times 2 \times 2$ factorial scheme, with five doses of biochar conilon coffee straw (Coffea canephora) (equivalent to 0, 5, 10, 15 and 20 $\mathrm{Mg} \mathrm{ha}^{-1}$ ), two irrigation waters (deionized water-DW and swine wastewater diluted to $50 \%$-SW50\%) and two soil textures (medium and clayey texture).

For the evaluation of the effect of textural differences, deformed samples of the B horizon (depth of 25 to $60 \mathrm{~cm}$ ) of a Red-Yellow Oxisol, of medium texture, and of a RedYellow Ultisol, of clay texture, were collected (USDA, 1999). The soils were collected starting horizon A, with the objective to reduce the effect of high levels of organic matter on the surface of the soil, in order to assess the maximum potential of treatments. Initially, before any other stage of the experiment, the soils were characterized chemically and physically, according to the methodology recommended by Embrapa (2017) (Table 1).

The biochar used was obtained from conilon coffee straw, from the processing of conilon coffee beans. The coffee straw passed through a pyrolysis reactor model SPPT-V60, installed in the experimental area of the Center for Agricultural Science and Engineering at the Federal University of Espírito Santo (CCAE/UFES). The carbonization temperature was $350{ }^{\circ} \mathrm{C}$, with an hour of residence in this temperature. The biochar was characterized in terms of $\mathrm{pH}$ values in water, ash content (Ac), cation exchange capacity - CEC and macro and micronutrient contents (Silva, 2009) (Table 2). After characterization, the biochar was passed through sieves of 2 and $0.5 \mathrm{~mm}$ mesh, being used the granulometry in this interval in the experiment.

The swine wastewater (SW) used in the experiment came from the farm located on the premises of Ifes Campus de Alegre. The SW was collected from the biofertilizer pond and transported to near of the greenhouse, where it was stored. The water was diluted in a 1:1 ratio with deionized water and stored in 50 liter drums. Before the implementation of the experiment, an undiluted SW sample was collected and sent for chemical analysis in a specialized laboratory, the results are shown in Table 3.

The collected soils were air dried, crushed and passed through $2 \mathrm{~mm}$ sieves. Subsequently, the soils were prepared to be incubated for a period of 35 days with dolomitic limestone ( $\mathrm{CaO} 32 \%, \mathrm{MgO}$ 14\%, PRNT 86\%) together with the different doses of biochar (equivalent 
to $0,10,15$ and $20 \mathrm{Mg} \mathrm{ha}^{-1}$ ), the biochar doses in $\mathrm{Mg} \mathrm{ha}^{-1}$, were extrapolated for the experiment in a greenhouse based on the transformation of the biochar dose in hectare, for the volume of soil used in each container (Experimental unit). Liming was performed to increase base saturation to $60 \%$, ideal for corn culture (Prezotti et al., 2007). The incubation was carried out in plastic bags with maintenance of humidity with the addition of water and homogenization with agitation.

In order to evaluate the initial effect of different doses of biochar on the chemical properties of the soil, in addition to obtaining the initial condition of the soil for each treatment, soil samples were collected after incubation (soil+limestone+biochar) to assess the chemical attributes (Embrapa, 2017) (Table 4).

The experimental units were composed of PVC tubes with $100 \mathrm{~mm}$ in diameter and $50 \mathrm{~cm}$ high, of which $45 \mathrm{~cm}$ were filled with soil, that is, $3.53 \mathrm{dm}^{3}$ of soil inside each tube. As the soils showed a difference in density (1.149 $\mathrm{kg} \mathrm{dm}^{-3}$ for medium textured soil and $1.016 \mathrm{~kg} \mathrm{dm}^{-3}$ for clayey soil), $4.05 \mathrm{~kg}$ of medium textured soil and $3.59 \mathrm{~kg}$ of clayey soil were required for each experimental unit corresponding to these soils.

The tubes had their internal walls sanded, in order to prevent irrigation water from taking a preferential path. The tubes were protected in the basal part by a shading material, with small holes $(<2 \mathrm{~mm})$, preventing the passage of the soil, but allowing good drainage.

The corn used was the hybrid AG 1051, a material suitable for grains and silage. Sowing took place on August 18, 2017, and the experiment was dismantled on October 21, 2017, 62 days after planting.

Deionized water and $50 \% \mathrm{SW}$ were added in sufficient quantity to make up around $50 \%$ of the total pore volume (TPV) (Bedin et al., 2003). The calculation used as basis the values of soil density ( $\mathrm{Sd})$ and particle density $(\mathrm{Pd})$ (Table 1), for medium texture and clay texture soils. The total pore volume was calculated using the formula $\mathrm{TPV}=\left\{1-\left(\frac{\mathrm{Sd}}{\mathrm{Pd}}\right)\right\} \times 100$, reaching values of $0.525 \mathrm{dm}^{3} \mathrm{dm}^{-3}$ and $0.602 \mathrm{dm}^{3} \mathrm{dm}^{-3}$, for medium and clay texture soils, respectively. Thus, to maintain $50 \%$ of TPV, it was necessary to $0.262 \mathrm{dm}^{3}$ of water in $1 \mathrm{dm}^{3}$ of medium texture soil and $0.301 \mathrm{dm}^{3}$ of water in $1 \mathrm{dm}^{3}$ of clayey soil. Then, weighing the set (tube + soil + water needed to maintain $50 \%$ of the TPV), the weight value for each experimental unit was found. Thus, the maintenance of soil moisture was performed through daily weighing of the experimental units.

Three fertilizations were carried out. Phosphate fertilization was carried out at planting with 3.07 and 3.21 grams/PVC tube with simple superphosphate $\left(19 \% \mathrm{P}_{2} \mathrm{O}_{5}\right)$

Table 1: Chemical and physical attributes (granulometric composition) of soils with different textural classes before the implementation of the experiment

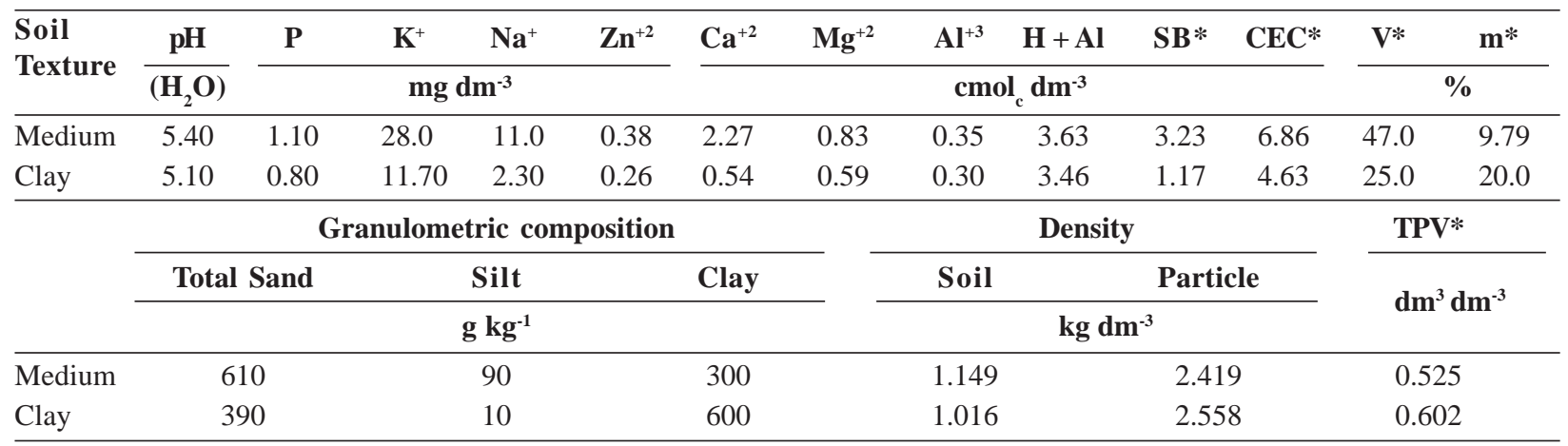

* SB: Sum of bases; CEC: Cation exchange capacity; V: Base saturation; m: aluminium saturation; TPV: total pore volume. Medium texture is Red-Yellow Oxisol; Clay texture is Red-Yellow Ultisol.

Table 2: Chemical characterization of the biochar from conilon coffee straw produced at a temperature of $350{ }^{\circ} \mathrm{C}$

\begin{tabular}{|c|c|c|c|c|c|c|c|c|c|c|}
\hline \multirow[t]{2}{*}{ Attribute } & \multirow{2}{*}{$\frac{\mathrm{pH}}{\mathrm{H}_{2} \mathrm{O}}$} & \multirow{2}{*}{$\begin{array}{c}\text { Ash } \\
\%\end{array}$} & \multirow{2}{*}{$\frac{\mathrm{CEC}}{\mathrm{cmol}_{\mathrm{c}} \mathrm{kg}^{-1}}$} & $\mathbf{Z n}$ & $\mathbf{C u}$ & $\mathbf{N}$ & $\mathbf{P}$ & $\mathbf{K}$ & $\mathbf{C a}$ & Mg \\
\hline & & & & \multicolumn{2}{|c|}{$\mathrm{mg} \mathrm{kg}^{-1}$} & \multicolumn{5}{|c|}{$\%$} \\
\hline Values & 8.9 & 13.6 & 296.9 & 28.8 & 37.5 & 3.5 & 0.04 & 6.2 & 0.1 & 0.09 \\
\hline
\end{tabular}

Table 3: Chemical characterization of swine wastewater

\begin{tabular}{|c|c|c|c|c|c|c|c|c|c|c|c|c|c|}
\hline \multirow{2}{*}{ Attribute } & \multirow{2}{*}{ pH } & $\mathrm{Fe}$ & $\mathbf{N a}$ & $\mathrm{Zn}$ & $\mathrm{Cu}$ & $\mathrm{PO}_{4}^{3-}$ & K & $\mathbf{C a}$ & $\mathrm{Mg}$ & B & Mn & $\mathrm{NO}_{3}^{-}$ & $\mathrm{NH}_{4}{ }^{+}$ \\
\hline & & \multicolumn{11}{|c|}{$\mathrm{mg} \mathrm{L}^{-1}$} & \\
\hline Values & 7.9 & 0.3 & 40.4 & 5.5 & 2.4 & 2.8 & 66.0 & 12.5 & 3.3 & 2.1 & 0.2 & 1.5 & 0.4 \\
\hline
\end{tabular}

Rev. Ceres, Viçosa, v. 68, n.6, p. 586-596, nov/dec, 2021 
for soils with medium and clayey texture, respectively. Nitrogen fertilizations were carried out in cover, at 21 and 45 days after planting, with 2.12 and 2.22 grams of ammonium sulfate $(21 \% \mathrm{~N})$, by PVC tube for clayey and medium soils, respectively, following recommendation by Oliveira et al. (1991). As there was a considerable increase in potassium in the soil due to incubation with biochar (Table 4), the potassium fertilization was not necessary.

To evaluate the variables associated with the soil, at the end of the experiment, corn plants were cut close to the soil, separating the aerial part from the root. The soil of each experimental unit was removed from the tubes, separated from the root, dried in the open air and homogenized. Samples of each treatment and repetition were collected for chemical determinations of $\mathrm{pH}$ in water, of $\mathrm{K}, \mathrm{Na}^{+}, \mathrm{Zn}^{+2}$ and $\mathrm{P}$ extracted with Mehlich-1 ( $\mathrm{HCl} 0.05$ mol L"1 $\left.+\mathrm{H}_{2} \mathrm{SO}_{4} 0.0125 \mathrm{~mol} \mathrm{L"1}\right)$ and determined by flame emission spectrophotometry $\left(\mathrm{K}^{+}\right.$and $\left.\mathrm{Na}^{+}\right)$, tomic absorption spectrophotometer $\left(\mathrm{Zn}^{+2}\right)$ and colorimetry $(\mathrm{P})$. Available calcium $\left(\mathrm{Ca}^{+2}\right)$ and magnesium $\left(\mathrm{Mg}^{+2}\right)$, were extracted with potassium chloride solution $\left(1 \mathrm{~mol} \mathrm{~L}{ }^{\text {"1 }}\right)$ and determined by atomic absorption spectrophotometer $\left(\mathrm{Ca}^{+2}\right.$ and $\mathrm{Mg}^{+2}$ ), according to methodology of Embrapa (2017).
The nutritional status of corn was evaluated by determining the levels of $\mathrm{N}, \mathrm{P}, \mathrm{K}, \mathrm{Ca}, \mathrm{Mg}$ and $\mathrm{Zn}$ in the aerial part of the plant, according to methodology of Silva (2009).

The data were submitted to analysis of variance, applying the $\mathrm{F}$ test $(\mathrm{p} \leq 0.05)$ to verify the significance of the effect of the factors and their interactions. In the case of significant effect for the interactions, the Tukey test was applied to compare means at $5 \%$ probability. In the case of significant interaction between the factors with the doses of biochar, the effect of the doses in each type of irrigation water and soil type was verified. The regression analysis of the significant factors was carried out, choosing the model of best fit according to the level of significance and the coefficient of determination. Sisvar was the statistical program used (Ferreira, 2011).

\section{RESULTS AND DISCUSSION}

\section{Soil nutrient content}

The levels of $\mathrm{P}, \mathrm{K}^{+}$and $\mathrm{Na}^{+}$were significantly higher for the two soils studied when irrigation was carried out with SW50\% (Table 5) and in interactions with all doses of biochar, except for $\mathrm{P}$ at doses of 0 and $5 \mathrm{Mg} \mathrm{ha}^{-1}$ (Table

Table 4: Average values of chemical attributes of soils of different textural classes after 35 days of incubation with biochar doses of conilon coffee straw and limestone

\begin{tabular}{|c|c|c|c|c|c|c|}
\hline \multirow{2}{*}{ Attribute } & \multirow{2}{*}{ Soil Texture } & \multicolumn{5}{|c|}{ Biochar doses $\left(\mathrm{Mg} \mathrm{ha}^{-1}\right)$} \\
\hline & & $\mathbf{0}$ & 5 & 10 & 15 & 20 \\
\hline \multirow[t]{2}{*}{$\mathrm{pH}$} & Medium & 6.32 & 6.42 & 6.39 & 6.55 & 6.75 \\
\hline & Clay & 6.29 & 6.29 & 6.38 & 6.42 & 6.58 \\
\hline \multirow{2}{*}{$\mathrm{P}\left(\mathrm{mg} \mathrm{dm}^{-3}\right)$} & Medium & 0.92 & 1.69 & 2.10 & 2.88 & 3.07 \\
\hline & Clay & 0.73 & 3.34 & 1.46 & 1.93 & 2.95 \\
\hline \multirow{2}{*}{$\mathrm{K}\left(\mathrm{mg} \mathrm{dm}^{-3}\right)$} & Medium & 15.34 & 110.34 & 175.00 & 245.50 & 390.67 \\
\hline & Clay & 28.83 & 109.17 & 169.84 & 253.00 & 361.00 \\
\hline \multirow{2}{*}{$\mathrm{Na}^{+}\left(\mathrm{mg} \mathrm{dm}^{-3}\right)$} & Medium & 4.50 & 3.00 & 3.00 & 3.67 & 4.00 \\
\hline & Clay & 7.50 & 8.00 & 8.67 & 9.67 & 10.17 \\
\hline \multirow{2}{*}{$\mathrm{Zn}^{+2}\left(\mathrm{mg} \mathrm{dm}^{-3}\right)$} & Medium & 0.32 & 0.64 & 0.36 & 0.37 & 0.39 \\
\hline & Clay & 0.53 & 0.44 & 0.49 & 0.51 & 0.54 \\
\hline \multirow{2}{*}{$\mathrm{Ca}^{+2}\left(\mathrm{cmol}_{\mathrm{c}} \mathrm{dm}^{-3}\right)$} & Medium & 1.80 & 1.30 & 1.30 & 1.50 & 1.30 \\
\hline & Clay & 2.70 & 2.80 & 2.80 & 2.90 & 2.80 \\
\hline \multirow{2}{*}{$\mathrm{Mg}^{+2}\left(\mathrm{cmol}_{\mathrm{c}} \mathrm{dm}^{-3}\right)$} & Medium & 1.02 & 0.91 & 0.93 & 0.99 & 0.91 \\
\hline & Clay & 1.00 & 1.04 & 1.01 & 1.02 & 1.01 \\
\hline \multirow{2}{*}{$\mathrm{H}+\mathrm{Al}\left(\mathrm{cmol}_{\mathrm{c}} \mathrm{dm}^{-3}\right)$} & Medium & 1.60 & 1.53 & 1.87 & 1.60 & 1.11 \\
\hline & Clay & 2.16 & 2.13 & 1.94 & 2.02 & 1.72 \\
\hline \multirow{2}{*}{$\mathrm{SB}\left(\mathrm{cmol}_{\mathrm{c}} \mathrm{dm}^{-3}\right)$} & Medium & 2.88 & 2.59 & 2.78 & 3.16 & 3.32 \\
\hline & Clay & 3.89 & 4.22 & 4.29 & 4.63 & 4.78 \\
\hline \multirow{2}{*}{$\mathrm{CEC}\left(\mathrm{cmol}_{\mathrm{c}} \mathrm{dm}^{-3}\right)$} & Medium & 4.43 & 4.12 & 4.65 & 4.76 & 4.47 \\
\hline & Clay & 6.05 & 6.35 & 6.23 & 6.66 & 6.50 \\
\hline \multirow{2}{*}{$\mathrm{V}(\%)$} & Medium & 65.96 & 63.52 & 59.80 & 66.33 & 75.34 \\
\hline & Clay & 64.42 & 66.35 & 69.02 & 70.05 & 73.92 \\
\hline
\end{tabular}


6). These results show the potential of the SW to increase these elements in the soil, corroborating the work carried out by Medeiros et al. (2011), who highlighted the contribution and increase of macronutrient and sodium contents in soil irrigated with SW100\% or diluted. Queiroz et al. (2004) also found similar results, where they observed an increase in the levels of $\mathrm{P}, \mathrm{K}^{+}$and $\mathrm{Na}^{+}$in soils treated with SW, even if for a short period (four months).

The clayey soil had a higher P content (Tables 5 and 7), this situation can be explained by some factors, initially, in general, the clay texture soil already had a higher $\mathrm{P}$ content than the medium texture soil (Table 4). To understand a fact that can corroborate with the maintenance of the highest $\mathrm{P}$ value in the clayey soil, it is necessary to know that the mineralogical composition of the clayey soil has a higher proportion of clay (60\%) than the medium textured soil (30\%), and with that the soil becomes a $\mathrm{P}$ drain, increasing the retention of this nutrient in the soil (Novais et al., 2007). According to Falcão \& Silva (2004), the adsorption of $\mathrm{P}$ varies depending on the mineralogical composition of the soil, with a positive correlation between the maximum adsorption capacity of $\mathrm{P}$ and the clay content in the soil. Despite the control of irrigation, it was observed percolation of WA and SW50\%

Table 5: $\mathrm{P}, \mathrm{K}^{+}$and $\mathrm{Na}^{+}$in medium and clayey soils cultivated with corn and irrigated with DW and SW50\%

\begin{tabular}{lccc}
\hline Nutrient & Soil Texture & DW & SW50\% \\
\hline $\mathrm{P}\left(\mathrm{mg} \mathrm{dm}^{-3}\right)$ & Clay & $16.2 \mathrm{Ab}$ & $20.3 \mathrm{Aa}$ \\
& Medium & $11.9 \mathrm{Bb}$ & $14.8 \mathrm{Ba}$ \\
\hline \multirow{2}{*}{$\mathrm{K}^{+}\left(\mathrm{mg} \mathrm{dm}^{-3}\right)$} & Clay & $110.3 \mathrm{Ab}$ & $226.6 \mathrm{Aa}$ \\
\hline \multirow{2}{*}{$\mathrm{Na}^{+}\left(\mathrm{mg} \mathrm{dm}^{-3}\right)$} & Medium & $84.5 \mathrm{Ab}$ & $263.9 \mathrm{Aa}$ \\
\hline
\end{tabular}

*DW: deionized water; SW50\%: swine wastewater diluted 50\% with deionized water; Same uppercase letters in the column and lowercase letters in the row do not differ at $5 \%$ probability by the Tukey test.

Table 6: $\mathrm{P}, \mathrm{K}^{+}$and $\mathrm{Na}^{+}$values in soils cultivated with corn irrigated with DW and SW50\%, in response to the application of different doses of biochar

\begin{tabular}{lccrrrr}
\hline \multirow{2}{*}{ Nutrient } & \multirow{2}{*}{ Irrigation water } & \multicolumn{5}{c}{ Biochar doses $\left(\mathbf{M g ~ h a}^{-1}\right)$} \\
\cline { 3 - 7 } & & $\mathbf{0}$ & $\mathbf{5}$ & $\mathbf{1 0}$ & $\mathbf{1 5}$ & $\mathbf{2 0}$ \\
\hline $\mathrm{P}\left(\mathrm{mg} \mathrm{dm}^{-3}\right)$ & $\mathrm{DW}$ & $11.3 \mathrm{~A}$ & $12.2 \mathrm{~A}$ & $14.4 \mathrm{~B}$ & $15.8 \mathrm{~B}$ & $16.4 \mathrm{~B}$ \\
& $\mathrm{SW50 \%}$ & $14.7 \mathrm{~A}$ & $14.4 \mathrm{~A}$ & $18.6 \mathrm{~A}$ & $19.1 \mathrm{~A}$ & $21.0 \mathrm{~A}$ \\
\hline \multirow{2}{*}{$\mathrm{K}^{+}\left(\mathrm{mg} \mathrm{dm}^{-3}\right)$} & $\mathrm{DW}$ & $26.0 \mathrm{~B}$ & $65.2 \mathrm{~B}$ & $89.0 \mathrm{~B}$ & $144.0 \mathrm{~B}$ & $163.0 \mathrm{~B}$ \\
& $\mathrm{SW50 \%}$ & $142.7 \mathrm{~A}$ & $191.2 \mathrm{~A}$ & $238.7 \mathrm{~A}$ & $297.0 \mathrm{~A}$ & $356.8 \mathrm{~A}$ \\
\hline \multirow{2}{*}{$\mathrm{Na}^{+}\left(\mathrm{mg} \mathrm{dm}^{-3}\right)$} & $\mathrm{DW}$ & $10.7 \mathrm{~B}$ & $10.8 \mathrm{~B}$ & $7.7 \mathrm{~B}$ & $9.7 \mathrm{~B}$ & $9.8 \mathrm{~B}$ \\
& SW50\% & $51.5 \mathrm{~A}$ & $46.7 \mathrm{~A}$ & $51.7 \mathrm{~A}$ & $45.7 \mathrm{~A}$ & $49.7 \mathrm{~A}$ \\
\hline
\end{tabular}

*DW: deionized water; SW50\%: swine wastewater diluted 50\% with deionized water; Same uppercase letters in the column do not differ at $5 \%$ probability by the Tukey test.

Table 7: $\mathrm{pH}, \mathrm{P}, \mathrm{K}$ and $\mathrm{Ca}^{+2}$ values in medium and clayey texture soils cultivated with corn in response to application of different doses of biochar

\begin{tabular}{|c|c|c|c|c|c|c|}
\hline \multirow{2}{*}{ Attribute } & \multirow{2}{*}{ Soil Texture } & \multicolumn{5}{|c|}{ Biochar doses $\left(\mathrm{Mg} \mathrm{ha}^{-1}\right)$} \\
\hline & & $\mathbf{0}$ & 5 & 10 & 15 & 20 \\
\hline \multirow{2}{*}{$\mathrm{pH}$} & Clay & $5.5 \mathrm{~A}$ & $5.4 \mathrm{~A}$ & $6.6 \mathrm{~A}$ & $5.6 \mathrm{~A}$ & $5.5 \mathrm{~A}$ \\
\hline & Medium & $5.5 \mathrm{~A}$ & $5.4 \mathrm{~A}$ & $5.5 \mathrm{~B}$ & $5.5 \mathrm{~A}$ & $5.6 \mathrm{~A}$ \\
\hline \multirow{2}{*}{$\mathrm{P}\left(\mathrm{mg} \mathrm{dm}^{-3}\right)$} & Clay & $13.5 \mathrm{~A}$ & $15.9 \mathrm{~A}$ & $20.0 \mathrm{~A}$ & $19.8 \mathrm{~A}$ & $22.0 \mathrm{~A}$ \\
\hline & Medium & $12.6 \mathrm{~A}$ & $10.8 \mathrm{~B}$ & $12.9 \mathrm{~B}$ & $15.1 \mathrm{~B}$ & 15.4B \\
\hline \multirow{2}{*}{$\mathrm{K}\left(\mathrm{cmol}_{\mathrm{c}} \mathrm{dm}^{-3}\right)$} & Clay & $77.0 \mathrm{~A}$ & $115.7 \mathrm{~A}$ & $156.8 \mathrm{~A}$ & $205.7 \mathrm{~A}$ & $257.5 \mathrm{~A}$ \\
\hline & Medium & $91.7 \mathrm{~A}$ & $140.7 \mathrm{~A}$ & $170.8 \mathrm{~A}$ & $235.3 \mathrm{~A}$ & $262.3 \mathrm{~A}$ \\
\hline \multirow{2}{*}{$\mathrm{Ca}^{+2}\left(\mathrm{cmol}_{\mathrm{c}} \mathrm{dm}^{-3}\right)$} & Clay & $2.5 \mathrm{~B}$ & $1.8 \mathrm{~B}$ & $1.8 \mathrm{~B}$ & $2.0 \mathrm{~B}$ & $2.0 \mathrm{~B}$ \\
\hline & Medium & $3.2 \mathrm{~A}$ & $3.3 \mathrm{~A}$ & $3.3 \mathrm{~A}$ & $3.4 \mathrm{~A}$ & $3.3 \mathrm{~A}$ \\
\hline
\end{tabular}

*Same uppercase letters in the column do not differ at $5 \%$ probability by the Tukey test.

Rev. Ceres, Viçosa, v. 68, n.6, p. 586-596, nov/dec, 2021 
of the tubes where the experiment was implanted. Thus, it assumes that as the SW50\% passes through the clay soil, $\mathrm{P}$ is retained, this situation that does not occur as efficiently in the average texture and the nutrient is lost through percolation. Situation reported by Toor \& Sims (2015) where greater interaction between soil particles (clay texture) and percolated water resulted in low $\mathrm{P}$ leaching.

When the $\mathrm{Ca}^{+2}$ content was analyzed, the medium textured soil had a significantly higher content than the clay textured soil (Table 7), which is due to its higher initial concentration (Table 4). When calculating the average of the $\mathrm{Ca}^{+2}$ content in the soil after incubation and at the end of the experiment, it appears that, proportionally, there was a greater increase in the clayey texture soil $(40.2 \%)$ in relation to the medium textured soil $(17.8 \%)$.

The levels of $\mathrm{P}$ and $\mathrm{K}^{+}$in the soil showed a linear increase as a function of the applied biochar doses (Figure $1 \mathrm{~A}, \mathrm{~B}, \mathrm{C}$ and $\mathrm{D})$. These results are associated with the high levels of these nutrients in the biochar (Table 2). Barbosa (2016), when characterizing biochars from coffee straw, observed high concentrations of phosphorus and, especially, potassium. And they can also be associated with the biochars chemical structure, which according to Petter \& Madari (2012) provide stability and reactivity to the soil, conditioned to the time of application, aromatic structures and functional groups, which will result in the accumulation and persistence of carbon in the soil, in greater or lesser amounts which will cause retention and availability of nutrients.

Another important fact is the alkaline characteristic of the biochar, as noted in Table 2, which can influence the nutriens availability, especially $\mathrm{P}$, which is more available in soil conditions with a pH close to 7.0 (Nóbrega, 2011). The $\mathrm{pH}$ of the environment influences the adsorption reactions of $\mathrm{P}$ and the solubilization of phosphates, interfering in the availability of $\mathrm{P}$ in the soil (Novais et al., 2007). According to Oliveira (2018), the biochar from conilon coffee straw has a zero charge point (ZCP) above 7.5 , a value higher than the $\mathrm{pH}$ of the soils studied in this experiment. In this way, the biochar surface will be protonated and will present an accumulation of positive charges, contributing to the anion exchange capacity, such as $\mathrm{H}_{2} \mathrm{PO}_{4}^{-}$, therefore, increasing the availability of $\mathrm{P}$ for plants. However, the application of biochar did not change the acidity of the soil, since no significant differences were observed between the $\mathrm{pH}$ with the increase of the applied doses (Table 7). These results demonstrate that the $\mathrm{pH}$ change was not the determining factor in increasing the availability of $\mathrm{P}$ in the soil.
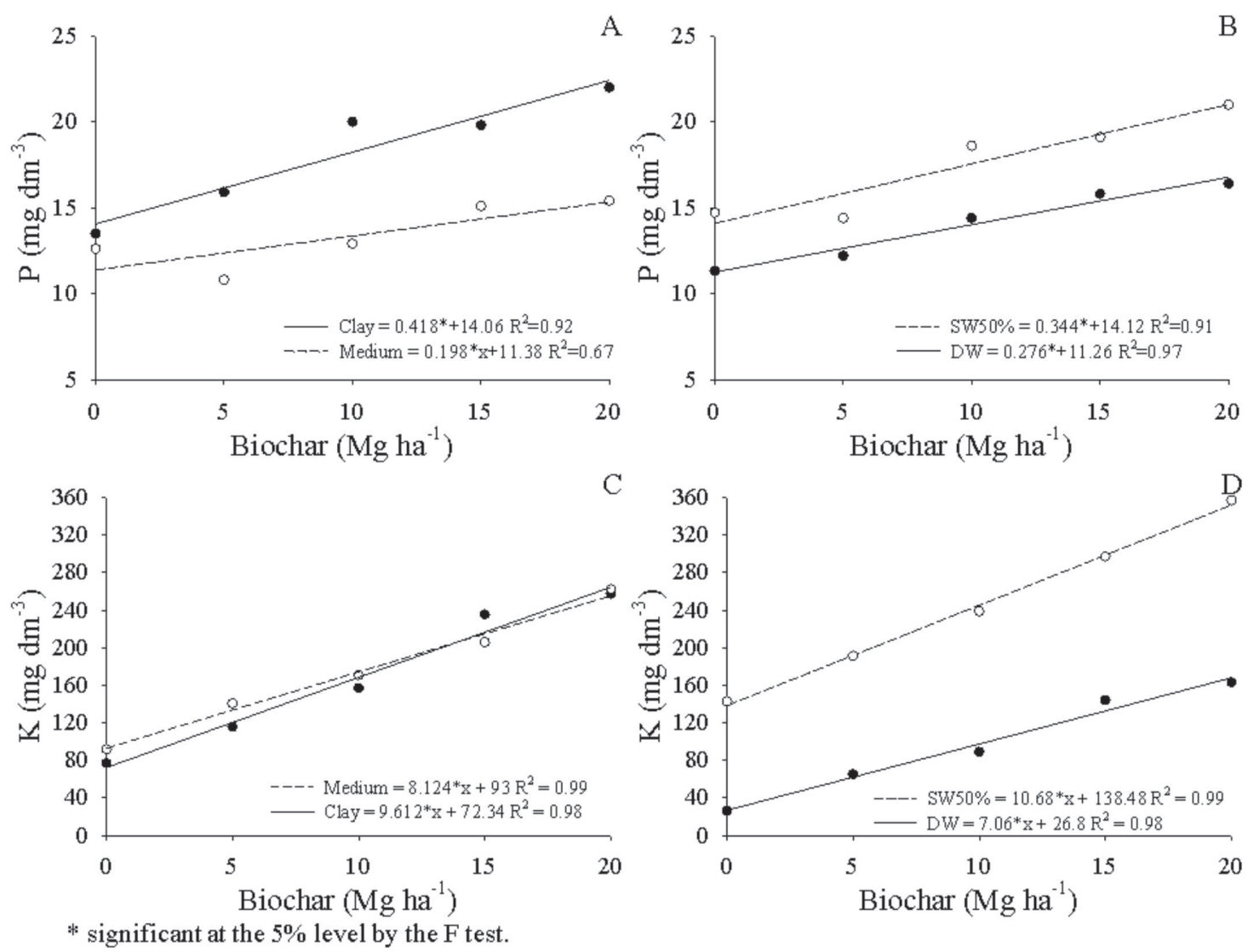

Figure 1: $\mathrm{P}$ and $\mathrm{K}^{+}$values in medium and clayey texture soils under corn cultivation irrigated with DW and SW50\% in response to the application of different doses of biochar. 
It was observed a synergistic effect between biochar and $\mathrm{SW} 50 \%$ in the increase of $\mathrm{P}$ and $\mathrm{K}^{+}$in the soil (Figures $1 \mathrm{~B}$ and $\mathrm{D})$. The increase in $\mathrm{K}^{+}$content in the soil is due to the high concentration of the nutrient in SW50\% (Table 3) and in the biochar from conilon coffee straw (Table 2). However, the high increase in $\mathrm{K}^{+}$must be accompanied, especially if there is an increase in the soil of $\mathrm{Na}^{+}, \mathrm{Ca}^{+2}, \mathrm{Mg}^{+2}$ because together, at high levels, they generate salinization causing a decrease in the productive potential of plants (Fernandes et al., 2019).

An important aspect about biochar is the presence of electrochemical adsorption sites on the surface of particles capable of retaining nutrients (Petter \& Madari, 2012). In a situation of low concentration of nutrients with saline potential in the soil, this characteristic of biochar is of great importance for maintaining fertility. However, according to Verheijen et al. (2010) salts contained in biochar in high concentrations, depending of the source of production, can cause secondary salinization of the soil. This fact reported by Da Costa et al. (2019) in their study, observing a linear increase of $45 \%$ in Ultisol ECs between zero dose and $1.5 \%$ biochar, independent of water salinity. In this sense, the use of SW, which contains saline elements in high concentrations, together with biochar, require further studies to better understand its interaction, especially when biochar presents saline elements in high concentrations.

The application of SW50\% did not significantly affect the levels of $\mathrm{Ca}^{+2}, \mathrm{Mg}^{+2}$ and $\mathrm{Zn}^{+2}$ in the studied soils, even though their concentrations are high in this residue. This result probably occurred due to the high consumption of these nutrients by the corn plant, which can be seen in Table 8, where the mineral nutrition of corn is compared between treatments under the influence of irrigation with DW and SW50\% in different doses of biochar.

\section{Nutrient content in the corn plant}

In general, irrigation with SW50\% increased the levels of $\mathrm{Ca}, \mathrm{Mg}$ and $\mathrm{Zn}$ in the dry mass of aerial part (DMAP) of corn, mainly when the plants were grown in medium texture soils (Table 8). Similar results were obtained by Oliveira $e t$ al. (2004), who, when using SW for corn irrigation, observed a higher concentration of $\mathrm{Ca}, \mathrm{Mg}$ and $\mathrm{Zn}$ in DMAP, when compared to common water.

The levels of $\mathrm{Mg}$ and $\mathrm{Zn}$ in DMAP in treatments with SW50\% were higher or equivalent to DW, except when the plant was grown in clayey soil and in the absence of biochar, which can be explained by the lower levels of $\mathrm{Zn}^{+2} \mathrm{e} \mathrm{Mg}^{+2}$ in the original clay soil.

Table 8: $\mathrm{Ca}, \mathrm{Mg}$ and $\mathrm{Zn}$ contents in the aerial part of corn plants grown in medium and clayey soils, irrigated with $50 \% \mathrm{DW}$ and $\mathrm{SW}$ and submitted to different doses of biochar

\begin{tabular}{|c|c|c|c|c|c|c|c|c|c|c|c|}
\hline \multirow{3}{*}{ Nutrient } & & \multicolumn{10}{|c|}{ Biochar doses $\left(\mathrm{Mg} \mathrm{ha}^{-1}\right)$} \\
\hline & & \multicolumn{2}{|r|}{$\mathbf{0}$} & \multicolumn{2}{|r|}{5} & \multicolumn{2}{|c|}{10} & \multicolumn{2}{|c|}{15} & \multicolumn{2}{|c|}{20} \\
\hline & & Clay & Medium & Clay & Medium & Clay & Medium & Clay & Medium & Clay & Medium \\
\hline \multirow{2}{*}{$\mathrm{Ca}\left(\mathrm{g} \mathrm{kg}^{-1}\right)$} & DW & $6.4 \mathrm{Ab}$ & $5.2 \mathrm{Bb}$ & $4.1 \mathrm{Bb}$ & $5.1 \mathrm{Ab}$ & $5.3 \mathrm{Ab}$ & $4.8 \mathrm{Ab}$ & $4.6 \mathrm{Ab}$ & $3.9 \mathrm{Bb}$ & 4.6Aa & $4.5 \mathrm{Ab}$ \\
\hline & SW50\% & $6.9 \mathrm{Ba}$ & 7.8Aa & $5.4 \mathrm{Ba}$ & $6.7 \mathrm{Aa}$ & $6.4 \mathrm{Aa}$ & $6.4 \mathrm{Aa}$ & $5.7 \mathrm{Ba}$ & $6.7 \mathrm{Aa}$ & $4.9 \mathrm{Ba}$ & $5.8 \mathrm{Aa}$ \\
\hline \multirow{2}{*}{$\operatorname{Mg}\left(\mathrm{g} \mathrm{kg}^{-1}\right)$} & DW & $6.8 \mathrm{Aa}$ & $4.5 \mathrm{Bb}$ & $2.7 \mathrm{Bb}$ & $3.3 \mathrm{Ab}$ & $3.3 \mathrm{Aa}$ & $2.8 \mathrm{Bb}$ & $2.8 \mathrm{Ab}$ & $2.2 \mathrm{Bb}$ & 3.0Aa & $1.9 \mathrm{Bb}$ \\
\hline & SW50\% & $5.1 \mathrm{Bb}$ & 7.2Aa & 3.1Ba & $4.5 \mathrm{Aa}$ & $3.3 \mathrm{Aa}$ & $3.5 \mathrm{Aa}$ & $3.2 \mathrm{Aa}$ & 3.1Aa & $3.1 \mathrm{Aa}$ & $3.3 \mathrm{Aa}$ \\
\hline \multirow{2}{*}{$\mathrm{Zn}\left(\mathrm{mg} \mathrm{kg}^{-1}\right)$} & DW & 61.0Aa & $45.3 \mathrm{Bb}$ & $22.4 \mathrm{Bb}$ & $41.4 \mathrm{Ab}$ & 29.7Ba & $39.4 \mathrm{Aa}$ & $31.0 \mathrm{Ba}$ & $39.4 \mathrm{Ab}$ & $24.7 \mathrm{Ab}$ & $30.7 \mathrm{Ab}$ \\
\hline & SW50\% & $53.4 \mathrm{Ab}$ & $57.0 \mathrm{Aa}$ & $33.4 \mathrm{Ba}$ & $57.4 \mathrm{Aa}$ & $32.0 \mathrm{Ba}$ & 42.0Aa & $29.0 \mathrm{Ba}$ & $50.4 \mathrm{Aa}$ & $33.0 \mathrm{Aa}$ & $38.4 \mathrm{Aa}$ \\
\hline
\end{tabular}

* DW: deionized water; SW50\%: swine wastewater diluted 50\% with deionized water; Same uppercase letters in the column and lowercase letters in the row do not differ at $5 \%$ probability by the Tukey test.

Table 9: Nitrogen, phosphorus and potassium contents in the aerial part of corn plants in medium and clayey texture soils, in response to irrigation with DW and SW50\%

\begin{tabular}{lccc}
\hline Nutrient & Soil Texture & DW & SW50\% \\
\hline $\mathrm{N}\left(\mathrm{g} \mathrm{kg}^{-1}\right)$ & Clay & $12.4 \mathrm{Ab}$ & $51.4 \mathrm{Aa}$ \\
& Medium & $7.4 \mathrm{Ab}$ & $44.7 \mathrm{Aa}$ \\
\hline $\mathrm{P}\left(\mathrm{g} \mathrm{kg}^{-1}\right)$ & Clay & $0.55 \mathrm{Ba}$ & $0.59 \mathrm{Ba}$ \\
& Medium & $0.62 \mathrm{Aa}$ & $0.72 \mathrm{Aa}$ \\
\hline \multirow{2}{*}{$\left(\mathrm{g} \mathrm{kg}^{-1}\right)$} & Clay & $25.4 \mathrm{Ab}$ & $33.0 \mathrm{Aa}$ \\
& Medium & $21.5 \mathrm{Bb}$ & $29.4 \mathrm{Ba}$ \\
\hline
\end{tabular}

*DW: deionized water; SW50\%: swine wastewater diluted 50\% with deionized water; Same uppercase letters in the column and lowercase letters in the row do not differ at $5 \%$ probability by the Tukey test.

Rev. Ceres, Viçosa, v. 68, n.6, p. 586-596, nov/dec, 2021 
As for the $\mathrm{N}$ content, the influence of irrigation water was observed, being higher in plants irrigated with SW50\% in both soils (Table 9) and in all doses of biochar, except $10 \mathrm{Mg} \mathrm{ha}^{-1}$ (Table 10), confirming the potential of $\mathrm{SW}$ in providing this nutrient. Authors highlight this positive effect in their work. Medeiros et al. (2015) and Guidinelle (2019) irrigated the corn with SW, for two consecutive cycles, and verified a significant increase in the $\mathrm{N}$ content in the plant's DMAP.

Corn plants when irrigated with DW showed N levels in the plant tissue below the range stated as idealized by Martinez et al. (1999), which corresponds to 27.5-32.5 g $\mathrm{kg}^{-1}$, however, when irrigated with SW50\%, the N content was higher than ideal for the crop $\left(<32.5 \mathrm{~g} \mathrm{~kg}^{-1}\right)$. In order to avoid high leaf values, Seganfredo (2000) recommends applications of SW with the criterion of defining the supply of the $\mathrm{N}$ necessary for the corn, avoiding the excess of this nutrient in the soil.

The $\mathrm{P}$ content in the DMAP was not influenced by the SW50\%, but were higher in plants grown in medium texture soils (Table 9). Regardless of the treatment, the levels of $\mathrm{P}$ in the plant tissue were below the ideal range described by Martinez et al. (1999), which corresponds to $2.5-3.5 \mathrm{~g} \mathrm{~kg}^{-1}$. This fact may be associated with clay soils that have a high $\mathrm{P}$ adsorption capacity, competing with plants for phosphorus applied in irrigation and via biochar, making the nutrient less available to be absorbed by plants (Novais et al., 2007). This result is supported by Bedin et al. (2003), when observing that even after a greater supply of $\mathrm{P}$ in the clayey soil than in the medium textured soil, corn plants absorbed less nutrient when cultivated in clayey soil.

The $\mathrm{K}$ content in the corn DMAP was influenced by irrigation water and soil texture, being higher in plants irrigated with SW50\% and cultivated under clayey soil (Table 9). SW50\% also increased the K content in DMAP when combined with biochar, except at doses of 10 and 20 $\mathrm{Mg} \mathrm{ha}^{-1}$ (Table 10). Costa (2017) reports that high concentrations of $\mathrm{Na}^{+}$in the soil can reduce the absorption of $\mathrm{K}^{+}$, with a consequent reduction in the content of this element in the corn leaf. This fact may explain the lower concentrations of $\mathrm{K}$ in plants grown in medium textured soil, which in its initial state has a higher concentration of sodium compared to clayey soil (Table 4).

The K content in corn DMAP was significantly higher in plants irrigated with SW50\%, even with the addition of exchangeable sodium to the soil. This result can be explained by the high supply of de K by SW, a rich source of this nutrient and, also, by the addition of biochar which helps to reduce the negative effects of $\mathrm{Na}^{+}$excesso in the soil.

However, no significant effect was observed between the increase in biochar doses and the decrease in $\mathrm{Na}^{+}$content. Unlike this study, Akhtar et al. (2015) observed that the addition of biochar in saline soil reduced the $\mathrm{Na}^{+}$absorption by wheat plants, due to its high capacity to adsorb this element and release $\mathrm{K}^{+}$in the soil solution.

Similar results were obtained by other authors. Effgen (2014) found higher K levels in Mombaça grass with the increase in the amount of SW used in irrigation. Oliveira et al. (2004) found K concentration in corn DMAP 2.3 times higher where SW was used. In the present work, the $\mathrm{K}$ content in the DMAP was approximately 1.3 times higher in the treatments with SW50\%, in relation to the plants irrigated with deionized water (DW). This may have occurred due to the dilution of SW in 50\% deionized water, reducing the concentration of the element in the residue.

Table 10: Nitrogen, Phosphorus and potassium contents in the aerial part of corn cultivated in medium and clayey texture soils irrigated with DW and SW50\%, in response to the application of different doses of biochar

\begin{tabular}{|c|c|c|c|c|c|c|}
\hline \multirow{2}{*}{ Nutrient } & \multirow{2}{*}{ Irrigation water } & \multicolumn{5}{|c|}{ Biochar doses $\left(\mathrm{Mg} \mathrm{ha}^{-1}\right)$} \\
\hline & & $\mathbf{0}$ & 5 & 10 & 15 & 20 \\
\hline \multirow{2}{*}{$\mathrm{N}\left(\mathrm{g} \mathrm{kg}^{-1}\right)$} & DW & $6.4 \mathrm{~B}$ & $10.1 \mathrm{~B}$ & $14.3 \mathrm{~A}$ & $9.4 \mathrm{~B}$ & $9.2 \mathrm{~B}$ \\
\hline & SW50\% & $60.3 \mathrm{~A}$ & $58.2 \mathrm{~A}$ & $41.5 \mathrm{~A}$ & $63.5 \mathrm{~A}$ & $46.6 \mathrm{~A}$ \\
\hline \multirow[b]{2}{*}{$\mathrm{P}\left(\mathrm{g} \mathrm{kg}^{-1}\right)$} & DW & $0.49 \mathrm{~A}$ & $0.57 \mathrm{~A}$ & $0.65 \mathrm{~A}$ & $0.58 \mathrm{~A}$ & $0.61 \mathrm{~A}$ \\
\hline & SW50\% & $0.51 \mathrm{~A}$ & $0.57 \mathrm{~A}$ & $0.65 \mathrm{~A}$ & $0.65 \mathrm{~A}$ & $0.63 \mathrm{~A}$ \\
\hline \multirow{2}{*}{$\mathrm{K}\left(\mathrm{g} \mathrm{kg}^{-1}\right)$} & DW & $5.5 \mathrm{~B}$ & $17.1 \mathrm{~B}$ & $30.0 \mathrm{~A}$ & $32.2 \mathrm{~B}$ & $32.4 \mathrm{~A}$ \\
\hline & SW50\% & $21.6 \mathrm{~A}$ & $26.4 \mathrm{~A}$ & $33.8 \mathrm{~A}$ & $37.4 \mathrm{~A}$ & $36.8 \mathrm{~A}$ \\
\hline \multicolumn{7}{|c|}{ texture soils } \\
\hline \multirow{2}{*}{$\mathrm{P}\left(\mathrm{g} \mathrm{kg}^{-1}\right)$} & Clay & $0.48 \mathrm{~A}$ & $0.54 \mathrm{~A}$ & $0.62 \mathrm{~A}$ & $0.58 \mathrm{~A}$ & $0.62 \mathrm{~A}$ \\
\hline & Medium & $0.52 \mathrm{~A}$ & $0.62 \mathrm{~A}$ & $0.69 \mathrm{~A}$ & $0.65 \mathrm{~A}$ & $0.63 \mathrm{~A}$ \\
\hline \multirow{2}{*}{$\mathrm{K}\left(\mathrm{g} \mathrm{kg}^{-1}\right)$} & Clay & $14.9 \mathrm{~A}$ & $25.6 \mathrm{~A}$ & $34.9 \mathrm{~A}$ & $34.8 \mathrm{~A}$ & $33.6 \mathrm{~A}$ \\
\hline & Medium & $12.2 \mathrm{~A}$ & $18.0 \mathrm{~A}$ & $28.8 \mathrm{~A}$ & $34.8 \mathrm{~A}$ & $33.6 \mathrm{~A}$ \\
\hline
\end{tabular}

*DW: deionized water; SW50\%: swine wastewater diluted 50\% with deionized water; Same uppercase letters in the column do not differ at $5 \%$ probability by the Tukey test. 
Even so, the $\mathrm{K}$ content in the plant tissue in DMAP is above the ideal range $\left(17.5-22.5 \mathrm{~g} \mathrm{~kg}^{-1}\right)$ described by Martinez et al. (1999) in all corn plants irrigated with SW50\%.

The $\mathrm{P}$ content in DMAP increased linearly in the interactions between clayey soil $\mathrm{x}$ biochar doses and SW50\% x biochar doses, and quadratically in the interactions between medium textured soil $\mathrm{x}$ biochar doses and DW $x$ biochar doses (Figures $2 \mathrm{~A}$ and $\mathrm{B}$ ), showing that, independently of the interaction, increasing doses of biochar were important to increase the absorption of $\mathrm{P}$ by corn plants. These results are in line with the statement of Lehmann \& Joseph (2009). According to the authors, biochar has high persistence in the soil with a high capacity for adsorption and release of nutrients, presenting residual effect when combined with different irrigation waters and soil type.

The $\mathrm{K}$ content in the aerial part of the corn grew linearly with the increase of biochar doses, regardless of the type of soil (Figure 2 C) and irrigation water (Figure 2 D). This behavior is similar to that seen in the soil, where the application of increasing doses of biochar guaranteed the linear increase of potassium. Therefore, it is believed that the growth and high content of this nutrient in the aerial part of corn is directly linked to its large contribution to the soil, due to the addition of biochar. This potassium linear increase in the aerial part of corn was different from that observed by Pinho et al. (2009), who verified a quadratic behavior during the corn crop cycle. However, the same authors pointed out that the peak of $\mathrm{K}$ absorption is in the initial phenological stages, where up to two thirds of $\mathrm{K}$ are accumulated by the plant, varying from the vegetative stage to the beginning of reproductive development, which roughly coincides with the duration of this experiment, 62 days of leading, and according to the authors, in the final stages of the corn crop cycle, after 90 days, there is no accumulation of $\mathrm{K}$, generating a quadratic curve.

It was also found that the combination of biochar and irrigation with SW50\% increased the K content in the aerial

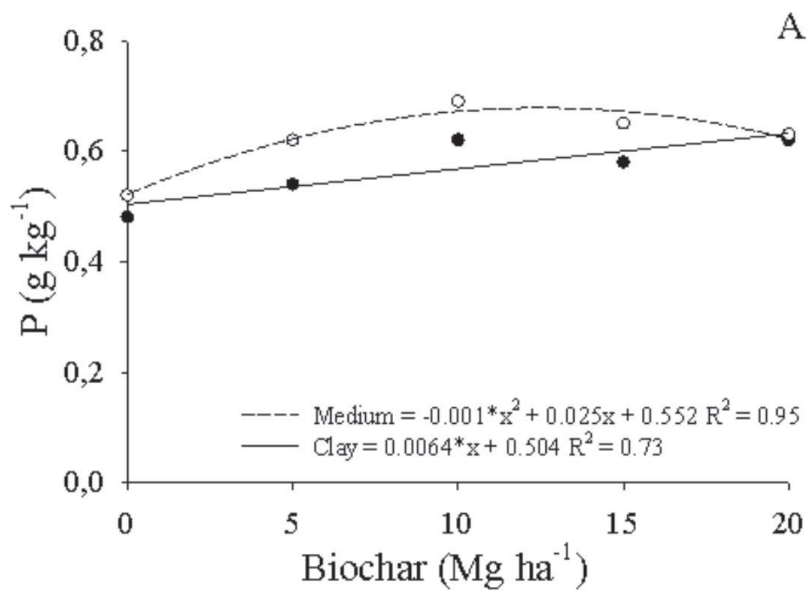

A
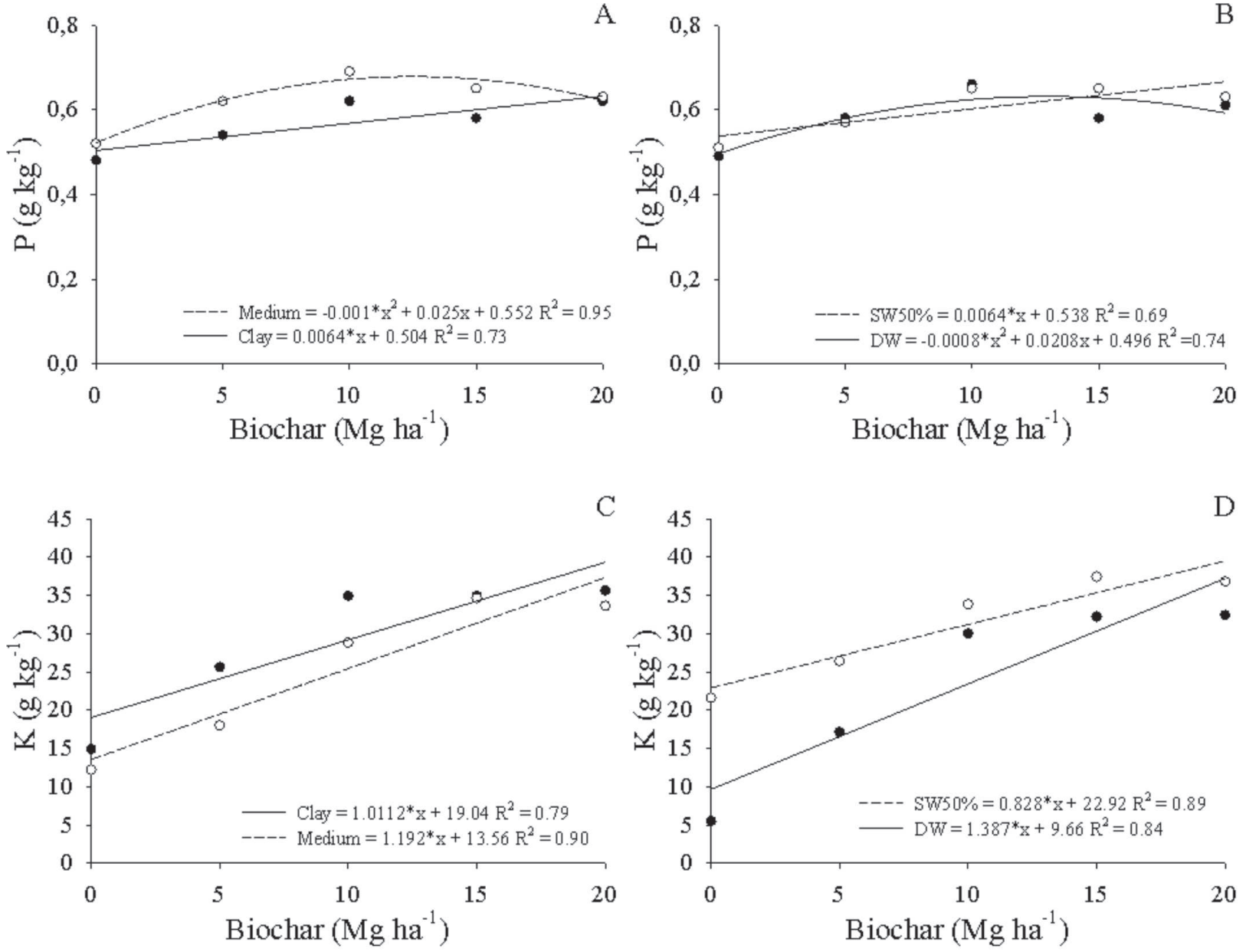

* significant at the $5 \%$ level by the $\mathrm{F}$ test.

Figure 2: Phosphorus and potassium contents in the aerial part of corn cultivated in medium and clayey texture soils irrigated with DW and SW50\%, in response to the application of different doses of biochar. 
part of the corn. This fact is related to the greater potassium supply to the soil due to the addition of biochar and SW50\%, associated with the high demand for the nutrient, which is the second most absorbed by the corn crop (Pinho et al., 2009).

\section{CONCLUSIONS}

Under the conditions of the present study, the addition of biochar doses linearly increased the levels of $\mathrm{P}$ and $\mathrm{K}$ in the soil, presenting a synergistic effect when combined with SW50\%, being a satisfactory alternative to increase soil fertility.

Irrigation with $50 \% \mathrm{SW}$, isolated or associated with biochar, increased the $\mathrm{Na}^{+}$content in the medium and clayey texture soils. Circumstance that due to the saline potential of $\mathrm{Na}^{+}$, deserves the development of new experiments with the application of doses of $100 \%$ of SW, to deepen the knowledge.

The agricultural use of biochar from conilon coffee straw was important to increase the content of $\mathrm{P}$ and, mainly, $\mathrm{K}$ in the aerial part of corn. In turn, SW50\% irrigation was important for increasing the levels of $\mathrm{N}, \mathrm{K}$, $\mathrm{Ca}, \mathrm{Mg}$ and $\mathrm{Zn}$ in the aerial part of the corn. Demonstrating that the joint application of the residues, presents itself as an alternative to increase the nutrition of the corn culture, providing a correct alternative for the destination of residues with polluting potential.

\section{ACKNOWLEDGEMENTS, FINANCIAL SUPPORT AND FULL DISCLOSURE}

To FAPES (Fundação de Amparo à Pesquisa e Inovação do Espírito Santo) for granting financial support.

There is no conflict of interests in the conduction and publication of this article.

\section{REFERENCES}

Akhtar SS, Andersen MN \& Liu F (2015) Residual effects of biochar on improving growth, physiology and yield of wheat under salt stress. Agricultural Water Management, 158:61-68.

Alvarenga AC (2019) Biocarvões de palha de café conilon sobre atributos do solo e desenvolvimento inicial e nutrição do cafeeiro conilon. Doctoral Thesis. Universidade Federal do Espírito Santo, Alegre. 108p.

Barbosa CF (2016) Caracterização de biocarvões de palha de café e casca de eucalipto Produzidos a 350 e $600{ }^{\circ} \mathrm{C}$. Master Dissertation. Universidade Federal do Espírito Santo, Alegre. $76 \mathrm{p}$

Bedin I, Resende AA, Neto AEF, Mendonça LA \& Vilela LCS (2003) Fontes de fósforo e crescimento do milho em solos com diferentes capacidades tampão de fosfato. Revista Ciência e Agrotecnologia, Edição Especial:1522-1531.

CONAB - Companhia Nacional De Abastecimento (2020) Acompanhamento da safra brasileira de café. Available at: https:// www.conab.gov.br/info-agro/safras/cafe. Accessed on: January $15^{\text {th }}, 2021$.
Costa ME (2017) Efeito do biochar e de águas salinas sobre o crescimento e nutrição do milho e na salinidade do solo. Doctoral Thesis. Universidade Federal Rural do Semi-Árido, Mossoró. 52p.

Da Costa ME, Do Nascimento EKÁ, De Oliveira MN, Pimenta AS, Dos Santos RAPM \& De Mendonça JAF (2019) Efeito do biochar sobre condutividade elétrica e $\mathrm{pH}$ de solos irrigados com água salina. Educamazônia-Educação, Sociedade e Meio Ambiente, 23:189-204.

Dal Bosco TC, Sampaio SC, Opazo MAU, Gomes SD \& Nóbrega LHP (2008) Aplicação de água residuária de suinocultura em solo cultivado com soja: cobre e zinco no material escoado e no solo. Engenharia Agrícola, 28:699-709.

Effgen EM (2014) Potássio no solo, na planta e produção de Capim Mombaça decorrente do uso de água residuária da suinocultura. Doctoral Thesis. Universidade Federal do Espírito Santo, Alegre. 81p.

EMBRAPA - Empresa Brasileira de Pesquisa Agropecuária (2017) Manual de métodos de análise de solo. $3^{\text {rd }}$ ed. Rio de Janeiro, Centro Nacional de Pesquisa de Solos. 573p.

Enders A, Hanley K, Whitman T, Joseph S \& Lehmann J (2012) Characterization of biochars to evaluate recalcitrance and agronomic performance. Bioresource Technology, 144:644-653.

Espírito Santo (2003) Instituto de Defesa Agropecuária e Florestal do Espirito Available at: https://idaf.es.gov.br/legislacao-idaf. Accessed on: January 14 ${ }^{\text {th }}, 2021$.

Falcão NPS \& Silva JRA (2004) Características de adsorção de fósforo em alguns solos da Amazônia Central. Acta Amazônica, 34:337-342.

Fernandes JD, Chaves LHG, Mendes JS, Chaves IB \& Tito GA (2019) Alterations in soil salinity with the use of different biochar doses. Revista de Ciências Agrárias, 42:89-98.

Ferreira DF (2011) Sisvar: a computer statistical analysis system. Ciência e Agrotecnologia, 35:1039-1042.

Fonseca AA, Santos DA, Passos RR, Andrade FV \& Rangel OJP (2020) Phosphorus availability and grass growth in biochar modified acid soil: a study excluding the effects of soil $\mathrm{pH}$. Soil Use and Management, 36:714-725.

Freitas WDS, Oliveira RA, Pinto FA, Cecon PR \& Galvão JCC (2004) Efeito da aplicação de águas residuárias de suinocultura sobre a produção do milho para silagem. Revista Brasileira de Engenharia Agrícola e Ambiental, 8:120-125.

Guidinelle RB (2019) Água residuária de suinocultura e sistema plantio direto no desenvolvimento do milho para produção de silagem. Master Dissertation. Instituto Federal do Espírito Santo, Alegre. 125p.

Lehmann J \& Joseph S (2009) Biochar for environmental management: An introduction. In: Lehmann J \& Joseph S (Ed.) Biochar for Environmental Management: Science and Technology. London, Earthscan. p.1-12.

Lehmann J \& Joseph S (2015) Biochar for environmental management: An introduction. In: Lehmann J \& Joseph S (Ed.) Biochar for Environmental Management: Science, Technology and Implementation. New York, Routledge. p.1-14.

Martinez HEP, Carvalho JG \& Souza RB (1999) Diagnose foliar. In: Ribeiro AC, Guimarães PTG \& Alvarez VVH (Ed.) Recomendações para uso de corretivos e fertilizantes em Minas Gerais: $5^{\text {a }}$ Aproximação. Viçosa, Comissão de Fertilidade do solo do Estado de Minas Gerais. p.143-168.

Medeiros SS, Gheyi HR, Pérez-Marin AM, Soares FAL \& Fernandes PD (2011) Características químicas do solo sob algodoeiro em área que recebeu água residuária da suinocultura. Revista Brasileira de Ciência do Solo, 35:047-1055. 
Medeiros SS, Perez-Marin AM, Júnior JAS, Reis CF \& Gheyi HR (2015) Potencial hídrico-nutricional da água residuária de suinocultura na irrigação do algodoeiro cultivado em condições semiáridas. Revista Irriga, 20:248-260.

Moreira EDS, Fernandes LA, Colen F \& Cruz ER (2015) Características agronômicas e produtividade de milho e milheto para silagem adubados com biofertilizante suíno sob irrigação. Boletim de Indústria Animal, 72:185-192.

Nóbrega ÍPC (2011) Efeitos do biochar nas propriedades físicas e químicas do solo: Sequestro de carbono no solo. Master Dissertation. Universidade Técnica de Lisboa, Lisboa. 46p.

Novais RF, Smyth TJ \& Nunes FN (2007) Fósforo. In: Novais RF, Alvarez VHV, Barros NF, Fontes RLF, Cantarutti RB \& Lima JC (Ed.) Fertilidade do solo. Viçosa, Sociedade Brasileira de Ciência do Solo. p.471-550.

Novotny EH (2014) Condicionador de solo à base de resíduos orgânicos carbonizados (biochar) e funcionalizados. In: Leite LFC, Maciel GA \& Araújo ASF (Ed.) Agricultura conservacionista no Brasil. Brasília, Embrapa. p. 341-363.

Oliveira AJ, Garrido WE, Araújo JD \& Lourenço S (1991) Métodos de pesquisa em fertilidade do solo. Brasília, Embrapa-SEA. $392 p$.

Oliveira RA, Freitas WS, Galvão JCC, Pinto FA \& Cecon PR (2004) Efeito da aplicação de águas residuárias de suinocultura nas características nutricionais do milho. Revista Brasileira de Milho e Sorgo, 3:357-369.

Oliveira YR (2018) Estudo da adsorção de Cu (II) utilizando biocarvão de palha de café conilon. Master Dissertation. Universidade Federal do Espírito Santo, Alegre. 40p.

Pereira ER (2006) Qualidade da água residuária em sistemas de produção e de tratamento de efluentes de suínos e seu reuso no ambiente agrícola. Doctoral Thesis. Escola Superior de Agricultura Luiz de Queiroz, Piracicaba. 131p.
Petter FA \& Madari BE (2012) Biochar: Agronomic and environmental potential in Brazilian savannah soils. Revista Brasileira de Engenharia Agrícola e Ambiental, 16:761-768.

Pinho RGV, Borges ID, Pereira JLAR \& Reis MC (2009) Marcha de absorção de macronutrientes e acúmulo de matéria seca em milho. Revista Brasileira de Milho e Sorgo, 8:157-173.

Pires AMM \& Mattiazzo ME (2008) Avaliação da viabilidade do uso de resíduos na agricultura. Jaguariúna, Embrapa Meio Ambiente. $9 \mathrm{p}$.

Prezotti LC, Gomes JA, Dadalto GG \& Oliveira JA (2007) Manual de Recomendação de Calagem e Adubação para o estado do Espírito Santo. Vitória, SEEA/INCAPER/CEDAGRO. 305p.

Queiroz FM, Matos AT, Pereira OG, Oliveira RA \& Lemos AF (2004) Características químicas do solo e absorção de nutrientes por gramíneas em rampas de tratamento de águas residuárias da suinocultura. Revista Engenharia na Agricultura, 12:77-90.

Seganfredo MA (2000) Análises do Risco de Poluição do Ambiente, quando se usa Dejetos de Suínos como Adubo do Solo. Concórdia, Embrapa Suínos e Aves. 3p.

Silva FCS (2009) Manual de análises químicas de solos, plantas e fertilizantes. $2^{\text {nd }}$ ed. Brasília, Embrapa Informação Tecnológica. $627 \mathrm{p}$.

Toor GS \& Sims JT (2015) Managing phosphorus leaching in mid Atlantic soils: Importance of legacy sources. Vadose Zone Journal, 14:1-12.

USDA - United States Department of Agriculture (1999) Soil Taxonomy: A Basic System of Soil Classification for Making and Interpreting Soil Surveys. $2^{\text {nd }}$ ed. Washington, Natural Resources Conservation Service. 886p.

Verheijen F, Jeffery S, Bastos AC, Velde M, Van DER \& Diafas I (2010) Biochar application to soils: a critical scientific review of effects on soil properties, processes and functions. Luxembourg, European Commission. 149p. 